\title{
Growth and yield of potato genotypes in the Brazilian Midwest ${ }^{1}$
}

\author{
Gabriel Emiliano Pereira², Carlos Francisco Ragassi ${ }^{3}$, \\ Agnaldo Donizete Ferreira de Carvalho ${ }^{3}$, Giovani Olegário da Silva ${ }^{3}$, Michelle Sousa Vilela ${ }^{2}$
}

\section{ABSTRACT}

The knowledge of the plant growth pattern under specific climatic conditions (growth curve) is the basis for exploiting the maximum yield potential of potato genotypes. This study aimed to establish the growth curve, as well as to evaluate the agronomic characteristics, yield and specific gravity of tubers of three potato cultivars and one elite clone, thus providing basic information on the productive characteristics of these genotypes in the Brazilian Midwest. A randomized experimental block design, with three replications, was used. The dry mass accumulated by the tubers varied from 6.28 (Agata) to $9.75 \mathrm{t} \mathrm{ha}^{-1}$ [F183-08-01 (F183)]; the total mass of tubers from 35.33 (BRSIPR Bel) to $58.60 \mathrm{tha}^{-1}$ (F183); the mass of marketable tubers from 23.46 (Asterix) to $48.24 \mathrm{t} \mathrm{ha}^{-1}$ (F183); and the leaf area index from 2.86 (Agata) to 10.60 (F183). F183 showed a good adaptation to the cultivation conditions of the Federal District, being strongly recommended for this region.

KEYWORDS: Solanum tuberosum, dry mass and photoassimilates accumulation, specific gravity.

\section{INTRODUCTION}

Potato (Solanum tuberosum L.) is the most planted vegetable crop worldwide. Brazil is not among the main potato producers, but the national production is significant in terms of area, being cropped for the fresh market and industry, and the main planted cultivars are Agata $(55 \%$ of the cultivated area) and Asterix (12\% of the cultivated area) (Abba 2019). These cultivars were developed for the climate and soil conditions of western Europe, which are distinct from the potato farming regions in Brazil.

\section{RESUMO}

Crescimento e produtividade de genótipos de batata no Centro-Oeste brasileiro

O conhecimento do padrão de crescimento da planta em condições climáticas específicas (curva de crescimento) é a base para explorar o potencial máximo de rendimento de genótipos de batata. Objetivou-se estabelecer a curva de crescimento e avaliar as características agronômicas, produtividade e gravidade específica de tubérculos de três cultivares e um clone elite, a fim de fornecer informações básicas sobre as características produtivas desses genótipos no Centro-Oeste brasileiro. Utilizou-se delineamento experimental de blocos ao acaso, com 3 repetições. A massa seca acumulada pelos tubérculos variou de 6,28 (Agata) a 9,75 $\mathrm{t} \mathrm{ha}^{-1}$ [F183-08-01(F183)]; a massa total de tubérculos de 35,33 (BRSIPR Bel) a 58,60 t ha ${ }^{-1}$ (F183); a massa de tubérculos comercializáveis de 23,46 (Asterix) a 48,24 t ha-1 (F183); e o índice de área foliar de 2,86 (Agata) a 10,60 (F183). F183 apresentou boa adaptação às condições de cultivo do Distrito Federal, sendo fortemente recomendado para essa região.

PALAVRAS-CHAVE: Solanum tuberosum, acúmulo de massa seca e de fotoassimilados, gravidade específica.

Potato farming occurs in 30 Brazilian regions, including seven states (Minas Gerais, São Paulo, Paraná, Rio Grande do Sul, Bahia, Goiás and Santa Catarina) and the Federal District (Silva \& Pereira 2019). If compared with Europe, photoperiods in Brazil are shorter in the summer, soils are less fertile, temperatures are higher and the frequency of plant diseases is higher (Pinto et al. 2010, Silva et al. 2017).

The development of cultivars adapted to Brazilian producing regions is strategic for boosting the potato farming sector (Silva et al. 2018). The BRSIPR Bel potato cultivar was developed by the potato breeding program of the Empresa Brasileira

\footnotetext{
${ }^{1}$ Received: July 08, 2020. Accepted: Oct. 29, 2020. Published: Nov. 25, 2020. DOI: 10.1590/1983-40632020v5064339.

${ }^{2}$ Universidade de Brasília, Faculdade de Agronomia e Medicina Veterinária, Brasília, DF, Brasil.

E-mail/ORCID: gb.emiliano28@gmail.com/0000-0003-3115-9893, michellevilelaunb@gmail.com/0000-0002-0417-568X.

${ }^{3}$ Empresa Brasileira de Pesquisa Agropecuária (Embrapa Hortaliças), Brasília, DF, Brasil.

E-mail/ORCID: carlos.ragassi@embrapa.br/0000-0003-3433-2567, agnaldo.carvalho@embrapa.br/0000-0001-5568-4874, giovani.olegario@embrapa.br/0000-0002-4587-3257.
} 
de Pesquisa Agropecuária (Embrapa) for cultivation in Brazil, being registered as a cultivar in 2012 (Pereira et al. 2015). F183-08-01 is an Embrapa's elite clone that stands out for its high tuber yield (about $56.88 \mathrm{t} \mathrm{ha}^{-1}$ ) (Bortoletto \& Silva 2016), and this genotype is undergoing the official registration process, in order to be released as a commercial cultivar: BRS 183 (Potira) (Pereira et al. 2020).

The potato farming region in Midwest Brazil occupied 5,500 ha in 2019, which corresponds to approximately $5 \%$ of the annual area cropped in the country (Cepea 2020). Information on potato growth patterns under Brazilian Midwest conditions is the basis for exploiting the productive potential of cultivars in this Brazilian potato farming region. Such growth patterns, also known as growth curves, are established individually for each genotype through the estimation of the dry mass accumulation by the plant parts over the production cycle (Fernandes et al. $2010 \mathrm{~b}$, Peixoto et al. 2011). The growth curve is also a tool for comparing the development of cultivars under certain growth conditions. This information can be used to design specific management practices for each cultivar and for the development of mathematical models for the potato crop.

Approximately $90 \%$ of the plant dry mass result from the photosynthetic activity and $10 \%$ from nutrient uptake and accumulation (Benincasa 2003). Thus, the longevity of the photosynthetic activity and the time for the plants to reach the maximum leaf area index are related to the plant dry mass accumulation (Fernandes et al. 2010b). The dry mass accumulation in the early stages of potato development occurs in the leaves, stems and roots, and is redirected towards the tubers about 34 days after planting, following the beginning of tuberization (Fernandes et al. 2010b).

This study aimed to establish the growth curve and evaluate the agronomic characteristics of yield and specific gravity of tubers of the BRSIPR Bel, Agata, Asterix and F183-08-01 cultivars, in order to provide basic information on the productive characteristics of these genotypes in the Brazilian Midwest.

\section{MATERIAL AND METHODS}

The experiment was carried out at an experimental field $\left(15^{\circ} 55^{\prime} \mathrm{S}, 48^{\circ} 08^{\prime} \mathrm{W}\right.$ and $1,000 \mathrm{~m}$ above the sea level), in Brasília, Federal District, Brazil. The climate is classified as Aw (humid tropical with a dry winter), according to the Köppen classification. On average, the annual temperatures range from $16.8{ }^{\circ} \mathrm{C}$ to $26.6{ }^{\circ} \mathrm{C}$ and the annual precipitation is $1,477.4 \mathrm{~mm}$. During the experiment, the temperatures ranged from $16.2{ }^{\circ} \mathrm{C}$ to $27.6{ }^{\circ} \mathrm{C}$ and the measured rainfall was $53 \mathrm{~mm}$ (Brasil 2019). The soil is classified as a Typic Hapludox (USDA 1999) or Latossolo Distrófico (Santos et al. 2018), with a clayey texture and the following chemical properties $(0-20 \mathrm{~cm}): \mathrm{pH}\left(\mathrm{H}_{2} \mathrm{O}\right): 5.2 ; \mathrm{P}$ (Mehlich): $1.0 \mathrm{mg} \mathrm{dm}^{-3}$; K: $46.2 \mathrm{mg} \mathrm{dm}^{-3}$; Na: $17.0 \mathrm{mg} \mathrm{dm}^{-3}$; B: $0.03 \mathrm{mg} \mathrm{dm}^{-3}$; Cu: $2.2 \mathrm{mg} \mathrm{dm}^{-3}$; Fe: $31.0 \mathrm{mg} \mathrm{dm}^{-3}$; Mn: $40.4 \mathrm{mg} \mathrm{dm}^{-3}$; Zn: $4.4 \mathrm{mg} \mathrm{dm}^{-3} ; \mathrm{S}: 2.0 \mathrm{mg} \mathrm{dm}^{-3}$; $\mathrm{Ca}^{2+}: 4.6 \mathrm{cmol}_{\mathrm{c}} \mathrm{dm}^{-3} ; \mathrm{Mg}^{2+}: 0.7 \mathrm{cmol}_{\mathrm{c}} \mathrm{dm}^{-3} ; \mathrm{Al}^{3+}$ : $0.0 \mathrm{cmol}_{\mathrm{c}} \mathrm{dm}^{-3} ; \mathrm{H}+\mathrm{Al}: 6.2 \mathrm{cmol}_{\mathrm{c}} \mathrm{dm}^{-3}$; organic matter: $33.7 \mathrm{~g} \mathrm{dm}^{-3}$. Fertilization was performed with $120 \mathrm{~kg} \mathrm{ha}^{-1}$ of N, $420 \mathrm{~kg} \mathrm{ha}^{-1}$ of $\mathrm{P}_{2} \mathrm{O}_{5}, 240 \mathrm{~kg} \mathrm{ha}^{-1}$ of $\mathrm{K}_{2} \mathrm{O}$ and $15 \mathrm{~kg} \mathrm{ha}^{-1}$ of $\mathrm{Zn}$, being applied in the planting furrow, and followed the recommendation for the Brazilian Midwest (Embrapa 2016).

Planting was carried out manually into furrows on May 15, 2018, using seeds standardized according to weight $(70 \mathrm{~g})$, sprouting length of $0.5-1.0 \mathrm{~cm}$, spaced $35 \mathrm{~cm}$ between plants and $80 \mathrm{~cm}$ between rows, with 35,714 plants ha $^{-1}$. An application of $90 \mathrm{~kg} \mathrm{ha}^{-1}$ of $\mathrm{N}$ as side dressing was made at the moment of hilling (22 days after planting - DAP). Sprinkling irrigation and phytosanitary management were carried out following recommendations for the Brazilian Midwest (Embrapa 2016).

A randomized experimental block design was used, with treatments (genotype $\times$ plant age) arranged in a split plot scheme, with three replications. The experiment was planned to the smallest size possible (four cultivars $\times$ three replications $=12$ main plots), since a great volume of work was necessary for collecting and processing the plant material on the same day. The main plots consisted of the Agata, Asterix, BRSIPR Bel and F183-08-01 potato genotypes, with six lines containing 15 plants each, totaling 90 plants and $25.2 \mathrm{~m}^{2}$, including the borders. The subplots were composed of four plants within a plot $\left(1.12 \mathrm{~m}^{2}\right)$ and corresponded to the plants ages, from which destructive samples of whole plants $(24,38,52,66$, 80, 94 and 112 DAP) were collected.

To estimate the dry mass accumulated by the different plant parts, the plants were washed and separated into stems + roots, leaves and tubers. The fresh and dry masses were determined using an 
analytical scale (Estefan et al. 2013). The longest stem length, number of stems and number of leaves were measured and the leaf area index was determined (Bréda 2003), from 38 to 80 DAP. The dry matter content in the tubers was determined by the ratio between the dry and fresh masses of the tubers. The plant senescence was evaluated weekly, beginning at $84 \mathrm{DAP}$, with the end of the production cycle being considered when $80 \%$ of the plants died in each plot (CIP 2009). Fifteen plants remaining in each plot completed the production cycle and were used to estimate the total and marketable yield, number of marketable tubers, crop cycle length, mass of individual tubers and tuber specific gravity, by the weight in air and water method (Fitzpatrick et al. 1969), at 122 DAP. Tuber production values were converted to $t^{-1} a^{-1}$, to obtain the tuber yield.

The data homogeneity was analyzed by the Levene test and the residue normality by the JarqueBera test. An analysis of variance was carried out using the $\mathrm{F}$ test $(\mathrm{p} \leq 0.05)$. The data obtained over the crop cycle (plants collected in the same plot at different times) were subjected to the sphericity test of the model. Regression analyses were carried out from these samples, while data from the other evaluations were separated into groups of means by the Tukey test $(p \leq 0.05)$. All statistical analyses were carried out using the R software.

\section{RESULTS AND DISCUSSION}

The overall analysis of variance considering the split-plot experiment (four cultivars $\times$ seven sampled plant development stadium) is presented in Table 1 . The dry mass accumulated by the tubers was evaluated from the tuber filling (36 DAP) to the end of the production cycle, totaling six collection times. The dry mass accumulated by the leaves and stems was evaluated from 24 to 80 DAP, at five collection times.

Significant differences were observed among the genotypes, with respect to the number of leaves per plant, length of the longest stem, number of stems per plant, leaf area index, vigor, dry matter content of tubers at 112 DAP, specific gravity of tubers, mass of individual tubers, total mass of tubers, mass of marketable tubers and length of the crop cycle (Tables 2 and 4). The genotypes did not differ, with respect to the number of marketable tubers.

The number of stems per plant, length of the longest stem, number of leaves and leaf area index did not present significant regression curves according to the analysis of variance. The coefficient of determination of the regression curves $\left(\mathrm{R}^{2}\right)$ was lower than $50 \%$ (data not shown). Data referring to the age of the plants, in which the highest values for this characteristic occurred, were considered for the analysis.

Asterix and Agata reached their maximum aboveground development at 52 DAP, while BRSIPR Bel and F183-081-01 reached it at 66 DAP (Figures 1A and 1B). Fernandes et al. (2010b) also noticed differences in the moment when different genotypes reached the maximum aboveground development. They observed that the genotypes reached values for maximum number of leaves and

Table 1. Analysis of variance and general mean of dry mass accumulated by leaves (DML) and stems (DMS) from 24 to 80 days after planting, and by tubers (DMT) from 36 to 112 days after planting.

\begin{tabular}{|c|c|c|c|c|c|c|}
\hline \multirow{2}{*}{ SV } & \multicolumn{2}{|c|}{ DML } & \multicolumn{2}{|c|}{ DMS } & \multicolumn{2}{|c|}{ DMT } \\
\hline & $\mathrm{DF}$ & MS & DF & MS & $\mathrm{DF}$ & MS \\
\hline Cultivar (C) & 3 & $154,047.97 * *$ & 3 & $21,976.55^{\text {ns }}$ & 3 & $4,280,701.69 * *$ \\
\hline Stadium (S) & 4 & $1,446,802.30^{* *}$ & 4 & $364,849.69^{* *}$ & 5 & $82,410,790.12 * *$ \\
\hline $\mathrm{C} \times \mathrm{S}$ & 12 & $37,525.27 * *$ & 12 & $10,770 \cdot 17^{\mathrm{ns}}$ & 15 & $1,723,683.61^{*}$ \\
\hline Residue & 32 & $16,764.26$ & 32 & $7,676.92$ & 39 & $753,076.65^{* *}$ \\
\hline \multirow[t]{2}{*}{ CV (\%) } & & 17.15 & & 23.43 & & 17.81 \\
\hline & & & & Means & & \\
\hline Agata & & $683.16 \mathrm{~b}^{/ 1}$ & & $346.27 \mathrm{a}$ & & $4,452.75 \mathrm{~b}$ \\
\hline Asterix & & $764.05 \mathrm{ab}$ & & $415.79 \mathrm{a}$ & & $4,824.13 \mathrm{~b}$ \\
\hline BRSIPR Bel & & $677.88 \mathrm{~b}$ & & $337.06 \mathrm{a}$ & & $4,638.63 \mathrm{~b}$ \\
\hline F183-08-01 & & $895.65 \mathrm{a}$ & & $396.70 \mathrm{a}$ & & $5,570.30 \mathrm{a}$ \\
\hline General mean & & 755.19 & & 373.96 & & $4,871.45$ \\
\hline
\end{tabular}

1/ Means followed by the same letter in the column do not differ by the Tukey test (5\%). ${ }^{\text {ns }}$ non-significant; ** significant ( $\left.1 \%\right)$; significant (5\%). SV: source of variation; MS: mean squares; DF: degrees of freedom; CV: coefficient of variation. 
Table 2. Number of stems (NS), length of the longest stem (LLS), number of leaves (NL) and leaf area index (LAI) of the potato crop at 52 days after planting.

\begin{tabular}{|c|c|c|c|c|c|c|c|c|}
\hline \multirow{2}{*}{ SV } & \multicolumn{2}{|c|}{ NS $\left(\right.$ plant $\left.^{-1}\right)$} & \multicolumn{2}{|c|}{$\operatorname{LLS}(\mathrm{cm})$} & \multicolumn{2}{|c|}{ NL $\left(\right.$ plant $\left.^{-1}\right)$} & \multicolumn{2}{|c|}{ LAI } \\
\hline & $\mathrm{DF}$ & MS & DF & MS & DF & MS & DF & MS \\
\hline Cultivar & 3 & $6.91 * *$ & 3 & $111.75^{*}$ & 3 & $441.94 *$ & 3 & $29.98 * *$ \\
\hline Residue & 6 & 0.44 & 5 & 14.26 & 5 & 40.46 & 6 & 1.47 \\
\hline $\mathrm{CV}(\%)$ & \multicolumn{2}{|c|}{15.09} & \multicolumn{2}{|r|}{7.28} & \multicolumn{2}{|r|}{13.74} & \multicolumn{2}{|c|}{17.80} \\
\hline & \multicolumn{8}{|c|}{ Means } \\
\hline Agata & \multicolumn{2}{|c|}{$5.33 \mathrm{a}^{/ 1}$} & \multicolumn{2}{|r|}{$48.00 \mathrm{~b}$} & \multicolumn{2}{|r|}{$44.67 \mathrm{a}$} & \multicolumn{2}{|r|}{$2.86 \mathrm{c}$} \\
\hline Asterix & \multicolumn{2}{|c|}{$6.00 \mathrm{a}$} & \multicolumn{2}{|r|}{$56.12 \mathrm{a}$} & \multicolumn{2}{|r|}{$56.33 \mathrm{a}$} & \multicolumn{2}{|r|}{$6.92 \mathrm{~b}$} \\
\hline BRSIPR Bel & \multicolumn{2}{|c|}{$3.17 \mathrm{~b}$} & \multicolumn{2}{|r|}{$45.17 \mathrm{~b}$} & \multicolumn{2}{|r|}{$29.75 b$} & \multicolumn{2}{|r|}{$6.83 \mathrm{~b}$} \\
\hline F183-08-01 & \multicolumn{2}{|c|}{$3.00 \mathrm{~b}$} & \multicolumn{2}{|r|}{$58.33 \mathrm{a}$} & \multicolumn{2}{|r|}{$54.42 \mathrm{a}$} & \multicolumn{2}{|c|}{$10.60 \mathrm{a}$} \\
\hline General mean & \multicolumn{2}{|c|}{4.38} & \multicolumn{2}{|r|}{51.90} & \multicolumn{2}{|r|}{46.29} & \multicolumn{2}{|r|}{6.81} \\
\hline
\end{tabular}

1/ Means followed by the same letter in the column do not significantly differ by the Tukey test (5\%). ** significant (1\%); significant (5\%). SV: source of variation; MS: mean squares; DF: degrees of freedom; CV: coefficient of variation.
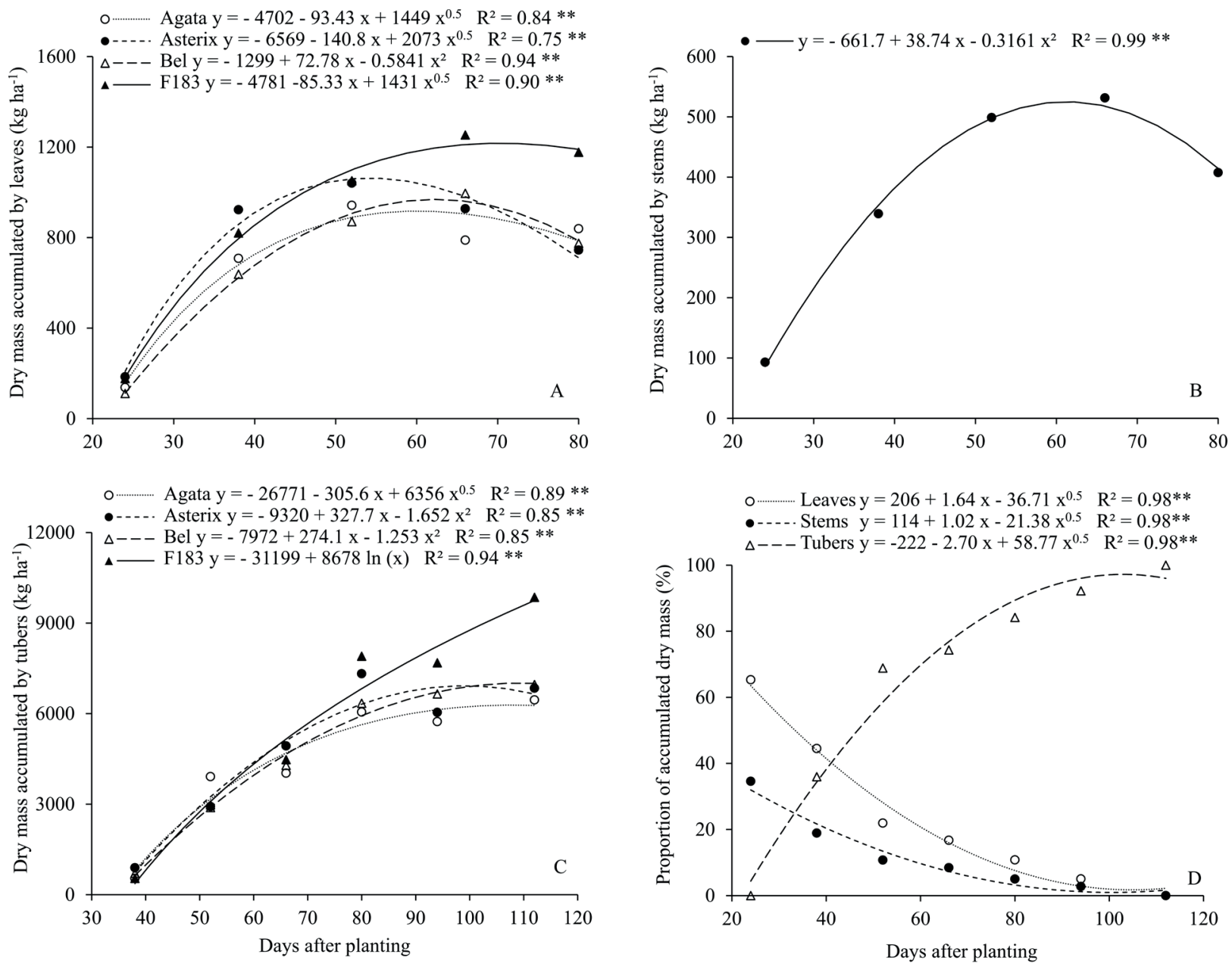

Figure 1. Dry mass accumulated by leaves (A), stems (B) and tubers (C), and proportion of accumulated dry mass (D) over the production cycle of the potato crop.

length of the longest stem at $63 \mathrm{DAP}$, on average, evaluated in the present study reached their values varying according to the genotype cycle length, for maximum number of leaves and length of the which was similar to the moment that the genotypes longest stem. 
Asterix and Agata showed a higher number of stems per plant than the other genotypes, with at least two stems per plant (Table 2). Fernandes et al. (2010b) observed similar numbers of stems per plant for these two cultivars, with 6.3 and 4.2 stems per plant produced, respectively. The number of stems per plant is influenced by the size and sprouting conditions of the seed tuber at the time of planting (Teixeira et al. 2010). However, the seed tubers used in this experiment were subjected to standardization, according to size and sprouting conditions. Thus, the variation observed in the number of stems per plant was probably influenced only by genetic factors (Feltran \& Lemos 2005).

According to Blauer et al. (2013), the number of produced tubers is proportional to the number of stems per plant, because the stems are independent, even if they originate from the same seed-piece. Thus, a high number of stems per seed-piece causes a high competition for water and nutrients, leading to the production of small and uneven tubers. However, this was not observed in relation to the number of tubers, in which no significant difference among the genotypes was observed, ranging from 3.4 to 5.0 marketable tubers per plant for Asterix and F183-08-01, respectively (data not shown). F183-08-01 had the highest mass of individual tubers and one of the smallest numbers of stems per plant. Agata and Asterix had the highest number of stems per plant and were among the genotypes with the lowest mass of individual tubers (Tables 2 and 4). These results show that the influence of the number of stems per plant of the genotypes on the number of commercial tubers was small.

F183-08-01 and Asterix plants were taller than BRSIPR Bel and Agata, when the length of the longest stem was observed (Table 2). Fernandes et al. (2010b) also evaluated the length of the longest stem of Asterix and Agata at the late stage of plant development and observed that these cultivars produced stems with an approximate length of 57 and $47 \mathrm{~cm}$, respectively. Feltran \& Lemos (2005) evaluated 18 potato genotypes and observed an average plant height of $56.6 \mathrm{~cm}$. They noticed that Asterix and Agata produced plants with heights equivalent to 58.1 and $52.8 \mathrm{~cm}$, respectively.

BRSIPR Bel had the lowest number of leaves per plant among the genotypes, but it produced a leaf area index equal to Asterix and higher than Agata (Table 2). This was due to the larger size of the BRSIPR Bel leaflets, when compared to the other genotypes, as it presented a leaf area index above the average, even with a lower number of leaves (Pereira et al. 2015). In addition, this cultivar produced one of the lowest numbers of stems per plant, which promoted a better plant architecture and better arrangement of leaves in the canopy. Such characteristics can be used to define the spacing between plants, because genotypes with lower numbers of stems per plant, length of the longest stem and number of leaves can be subjected to higher plant/tuber density at sowing.

According to Benincasa (2003), $90 \%$ of the dry mass accumulated by plants results in photosynthetic activity, while the remaining $10 \%$ are for nutrient uptake. Thus, a larger leaf area corresponds to a higher photosynthetic activity, and, consequently, higher dry mass production. This relationship was also observed in the current study, in which there was a high positive phenotypic correlation $(r=0.73)$ between the mass of marketable tubers and the leaf area index (Table 3).

Table 3. Correlation coefficients among characters of the potato crop.

\begin{tabular}{|c|c|c|c|c|c|c|c|c|c|}
\hline Character & $\mathrm{SG}$ & TMT & MMT & $\mathrm{CCL}$ & MIT & LLS & $\mathrm{NL}$ & LAI & DMC \\
\hline $\mathrm{SG}$ & 1 & $0.35^{\mathrm{ns}}$ & $0.56^{\mathrm{ns}}$ & $0.75 * *$ & $0.64 *$ & $0.19^{\mathrm{ns}}$ & $-0.43^{\mathrm{ns}}$ & $0.78 * *$ & $0.93 * *$ \\
\hline TMT & & 1 & $0.94 * *$ & $0.83 * *$ & $0.82 * *$ & $0.61 *$ & $0.26^{\mathrm{ns}}$ & $0.60 *$ & $0.40^{\mathrm{ns}}$ \\
\hline MMT & & & 1 & $0.93 * *$ & $0.87 * *$ & $0.58 *$ & $0.14^{\mathrm{ns}}$ & $0.73 * *$ & $0.58 *$ \\
\hline CCL & & & & 1 & $0.92 * *$ & $0.60 *$ & $-0.01^{\text {ns }}$ & $0.82 * *$ & $0.74 * *$ \\
\hline MIT & & & & & 1 & $0.69 *$ & $0.10^{\mathrm{ns}}$ & $0.78 * *$ & $0.63 *$ \\
\hline LLS & & & & & & 1 & $0.62 *$ & $0.68 *$ & $0.35^{\mathrm{ns}}$ \\
\hline NL & & & & & & & 1 & $0.13^{\text {ns }}$ & $-0.19^{\text {ns }}$ \\
\hline LAI & & & & & & & & 1 & $0.89 * *$ \\
\hline DMC & & & & & & & & & 1 \\
\hline
\end{tabular}

Values in bold are significantly correlated. * significant at $5 \%$ of probability; ** significant at $1 \%$ of probability; ${ }^{\text {ns }}$ non-significant. SG: specific gravity; TMT: total mass of tubers; MMT: marketable mass of tubers; CCL: crop cycle length; MIT: mas of individual tuber; LLS: length of the longest stems; NL: number of leaves; LAI: leaf area index; DMC: dry mass content of tubers at 112 days after planting. 
Table 4. Dry matter content of tubers at 112 days after planting (DMC), tuber specific gravity (SG), mass of individual tubers (MIT), total mass of tubers (TMT), mass of marketable tubers (MMT) and crop cycle length (CCL) of potato genotypes.

\begin{tabular}{|c|c|c|c|c|c|c|c|c|c|c|c|c|}
\hline \multirow{2}{*}{ SV } & \multicolumn{2}{|c|}{$-\mathrm{DMC}(\%)-$} & \multicolumn{2}{|c|}{$\mathrm{SG}$} & \multicolumn{2}{|c|}{$-\operatorname{MIT}(\mathrm{g})-$} & \multicolumn{2}{|c|}{ - TMT $\left(\mathrm{t} \mathrm{ha}^{-1}\right)-$} & \multicolumn{2}{|c|}{$-\operatorname{MMT}\left(\mathrm{t} \mathrm{ha}^{-1}\right)-$} & \multicolumn{2}{|c|}{- CCL (days) - } \\
\hline & $\mathrm{DF}$ & MS & DF & MS & $\mathrm{DF}$ & MS & DF & MS & DF & MS & DF & MS \\
\hline Cultivar & 3 & $19.32 * *$ & 3 & $0.0005 * *$ & 3 & $5,700.6^{* *}$ & 3 & $363.09 * *$ & 3 & $409.91 * *$ & 3 & $172.22 * *$ \\
\hline Residue & 5 & 0.18 & 6 & 0.00001 & 6 & 135.92 & 6 & 16.67 & 6 & 16.44 & 6 & 6.81 \\
\hline$\overline{\mathrm{CV}(\%)}$ & & 2.35 & & 0.30 & & 5.68 & & 9.59 & & 13.16 & & 2.35 \\
\hline \multicolumn{13}{|c|}{ Means } \\
\hline Agata & & $14.68 \mathrm{c}^{1 /}$ & & $1.06 \mathrm{c}$ & & $175.45 \mathrm{~b}$ & & $40.90 \mathrm{~b}$ & & $25.14 \mathrm{~b}$ & & $105.00 \mathrm{~b}$ \\
\hline Asterix & & $17.62 \mathrm{~b}$ & & $1.07 \mathrm{~b}$ & & $193.08 \mathrm{~b}$ & & $35.44 \mathrm{~b}$ & & $23.46 \mathrm{~b}$ & & $107.30 \mathrm{~b}$ \\
\hline BRSIPR Bel & & $20.21 \mathrm{a}$ & & $1.08 \mathrm{a}$ & & $183.03 \mathrm{~b}$ & & $35.33 \mathrm{~b}$ & & $26.36 \mathrm{~b}$ & & $109.70 \mathrm{~b}$ \\
\hline F183-08-01 & & $20.34 \mathrm{a}$ & & $1.09 \mathrm{a}$ & & $269.83 \mathrm{a}$ & & $58.60 \mathrm{a}$ & & $48.24 \mathrm{a}$ & & $122.00 \mathrm{a}$ \\
\hline General mean & & 18.21 & & 1.07 & & 205.35 & & 42.56 & & 30.80 & & 111.00 \\
\hline
\end{tabular}

1/ Means followed by the same letter in the column do not significantly differ by the Tukey test (5\%). ${ }^{\text {ns }}$ non-significant; ** significant (1 \%). SV: source of variation; MS: mean squares; DF: degrees of freedom; CV: coefficient of variation.

On the other hand, the number of leaves per plant at the maximum aboveground development stage was weakly correlated with the mass of marketable tubers $(\mathrm{r}=0.14)$ (Table 3). Therefore, the tuber yield could be estimated through the leaf area index more efficiently than the number of leaves at the maximum aboveground development. The maximum leaf area index of the evaluated genotypes occurred at 52 DAP for Asterix and Agata, and at 66 DAP for BRSIPR Bel and F183-08-01. Pohl et al. (2009) observed that the potato genotypes they evaluated had the highest leaf area index, on average, at 60 DAP.

No significant differences were observed among the genotypes, with respect to the leaf dry mass accumulation, until 52 DAP (Figure 1A). However, the leaf dry mass accumulation for F183-08-01 was higher than that for the other genotypes from 66 to 80 DAP. Asterix reached the maximum leaf dry mass accumulation earlier than all the other genotypes at $54 \mathrm{DAP}\left(1,063 \mathrm{~kg} \mathrm{ha}^{-1}\right)$, followed by Agata at $60 \mathrm{DAP}$ (917.4 $\left.\mathrm{kg} \mathrm{ha}^{-1}\right)$, BRSIPR Bel at 62 DAP $\left(968.9 \mathrm{~kg} \mathrm{ha}^{-1}\right)$ and F183-08-01 at 70 DAP $\left(1,217 \mathrm{~kg} \mathrm{ha}^{-1}\right)$. The stem dry mass was the same for all the genotypes, since no significant difference among the cultivars or for the interaction between cultivars and plant age was observed, and its response was represented by a single curve (Figure 1B). The maximum estimated stem dry mass was $525.1 \mathrm{~kg} \mathrm{ha}^{-1}$ at 61 DAP.

No significant difference was observed among the genotypes, regarding the tuber dry mass accumulation, until 66 DAP (Figure 1C). However, a significant difference $(\mathrm{p} \leq 0.05)$ was observed between F183-08-01 and Agata, from 80 DAP to 94 DAP (Figure 1C). At 112 DAP, F183-08-01 had the highest tuber dry mass accumulation among the evaluated genotypes $\left(9,748 \mathrm{~kg} \mathrm{ha}^{-1}\right)$. Asterix obtained the highest tuber dry mass accumulation at 99 DAP $\left(6,922 \mathrm{~kg} \mathrm{ha}^{-1}\right)$, while Agata reached the highest tuber dry mass accumulation at 108 DAP $\left(6,284 \mathrm{~kg} \mathrm{ha}^{-1}\right)$ and BRSIPR Bel at 109 DAP $\left(7,011 \mathrm{~kg} \mathrm{ha}^{-1}\right)$.

The senescence of the older leaves started after the maximum shoot development (52 DAP for Agata and Asterix, and 66 DAP for BRSIPR Bel and F18308-01), reducing the number of photosynthetically active leaves until the complete senescence of the plants, as can be seen in the leaf dry mass (Figure 1A). The highest leaf dry mass accumulation of Asterix and Agata occurred at 52 DAP (Figure 1A). This was because the senescence rate surpassed the emission rate of new leaves (Pohl et al. 2009).

In addition to the knowledge on tuber growth and development, knowing the dynamics of the formation and maintenance of leaves and stems is also important, since they are responsible for the photoassimilate production processes, and approximately $90 \%$ of the plant mass result from photosynthetic activity. Photoassimilates are first accumulated in the leaves and stems, and then translocated into the tubers, following the beginning of tuberization, which occurs approximately at 30 DAP (Fernandes et al. 2011). This translocation process begins at the early tuber formation and tends to accelerate with the crop development, gradually decreasing at the end of the growth cycle, and finishing with plant senescence (Fernandes et al. 2010b).

The shoot dry mass(leaf dry mass accumulation+ stem dry mass) surpassed the dry mass accumulated by tubers from the emergence until 38 DAP (Figure 1D). At 52 DAP, the tubers corresponded 
to $67 \%$ of the total dry mass accumulated by the plants, similarly to the period observed by Cantore et al. (2014) and Fernandes et al. (2010b). Although the tubers were the main photoassimilate sink from 52 DAP until the end of the production cycle (Figures $1 \mathrm{C}$ and 1D), the leaf dry mass increased until 60 DAP for Agata, 54 DAP for Asterix, 62 DAP for BRSIPR Bel and 70 DAP for F183-08-01. The tuber dry mass accumulation by F183-08-01 was higher than that by Agata, Asterix and BRSIPR Bel, which were about $3,464 \mathrm{~kg} \mathrm{ha}^{-1}, 2,826 \mathrm{~kg} \mathrm{ha}^{-1}$ and $2,737 \mathrm{~kg} \mathrm{ha}^{-1}$, respectively, at 112 DAP (Figure 1C). The total mass of the tubers, mass of marketable tubers, mass of individual tubers and production cycle length of F183-08-01 were also superior to the other genotypes (Table 4).

In addition to the high yield, resistance to biotic and abiotic stresses, regular tuber size, good appearance and shape, the tubers must have a high dry matter content, in order to suit industrial processing. The absence of physiological disorders, low levels of reducing sugars and high starch levels are some of the internal attributes of tubers that are responsible for the variation in the dry matter content (Melito et al. 2017). The direct determination of the dry matter content in tubers is a time-consuming process (Estefan et al. 2013) that limits the processing yield. The tuber specific gravity is commonly used by the potato processing industry to infer the dry matter content of tubers. In this research, it was possible to validate the specific gravity as a method for indirectly determining the dry matter content in the tubers, as these two characteristics showed a strong direct correlation $(r=0.93)$ (Table 3). Kumar et al. (2005), carrying out various evaluations of the specific gravity and dry matter content in the tubers, defined a table with reference values associating the specific gravity and dry matter content in tubers and found that tubers with a specific gravity above 1.080 present a tuber dry matter content suitable for industrial processing.

A tuber specific gravity above 1.080 was observed in BRSIPR Bel and F183-08-01 (Table 4). According to this parameter, BRSIPR Bel and F18308-01 are suitable for industrial potato processing. The determination of starch and reducing sugar levels is necessary to confirm their suitability for this purpose (Fernandes et al. 2010a). Although the Asterix cultivar is widely used for industrial processing (Abba 2010), its tubers did not reach a specific gravity of 1.080 in this study (Table 4). On the other hand, the suitability of Agata for consumption was confirmed by specific gravity values below 1.080 .

The dry matter content of the tubers at 112 DAP differed among the genotypes in the same way that the specific gravity differed (Table 4), what is in agreement with the correlation observed between these two parameters $(\mathrm{r}=0.93)$ (Table 3$)$. The specific gravity values obtained at 122 DAP converted to the dry matter content, as proposed by Kumar et al. (2005), corresponded to $13.63 \%$ for Agata, $16.57 \%$ for Asterix, $19.90 \%$ for BRSIPR Bel and $20.47 \%$ for F183-08-01. Fernandes et al. (2010a) observed similar values of dry matter content for the Asterix $(16.70 \%)$ and Agata (14.10\%) cultivars.

\section{CONCLUSIONS}

1. The elite clone F183-08-01 showed the highest dry mass accumulated by the tubers, total mass and marketable mass of tubers, mass of individual tubers and leaf area index, and the lowest variation in the rate of dry mass accumulation in the tubers among the genotypes;

2. The higher leaf area index of F183-08-01 favored the greater accumulation of dry mass in the plant organs, probably due to the greater efficiency in capturing photosynthetically the active radiation;

3. F183-08-01 showed a good adaptation to the cultivation conditions of the Federal District, being strongly recommended for this region.

\section{ACKNOWLEDGMENTS}

We thank the Empresa Brasileira de Pesquisa Agropecuária (Embrapa) and Coordenação de Aperfeiçoamento de Pessoal de Nível Superior (Capes).

\section{REFERENCES}

ASSOCIAÇÃO BRASILEIRA DA BATATA (Abba). Brasil: atuais variedades. Batata Show, v. 10, n. 28, p. 1-68, 2010.

ASSOCIAÇÃO BRASILEIRA DA BATATA (Abba). Quem define as variedades de batata no Brasil? Batata Show, v. 19, n. 55, p. 1-33, 2019.

BENINCASA, M. M. P. Análise de crescimento de plantas: noções básicas. 2. ed. Jaboticabal: Funep, 2003. 
BLAUER, J. M.; KNOWLES, L. O.; KNOWLES, N. R. Manipulating stem number, tuber set and size distribution in specialty potato cultivars. American Journal of Potato Research, v. 90, n. 5, p. 470-496, 2013.

BORTOLETTO, A. C.; SILVA, G. O. Validação de clones avançados de batata da Embrapa na indústria. Batata Show, v. 16, n. 46, p. 52-55, 2016.

BRASIL. Instituto Nacional de Meteorologia. Estações automáticas. Brasília, DF: INMET, 2019.

BRÉDA, N. J. J. Ground-based measurements of leaf area index: a review of methods, instruments and current controversies. Journal of Experimental Botany, v. 54, n. 392, p. 2403-2417, 2003.

CANTORE, V.; WASSAR, F.; YAMAÇ, S. S.; SELLAMI, M.H.;ALBRIZIO, R.; STELLACCI,A. M.; TODOROVIC, M. Yield and water use efficiency of early potato grown under different irrigation regimes. International Journal of Plant Production, v. 8, n. 3, p. 409-428, 2014.

CENTRODE ESTUDOS AVANÇADOS EM ECONOMIA APLICADA (Cepea). Anuário 2019-2020. Piracicaba: Cepea, 2020.

CENTRO INTERNACIONAL DE LA PAPA (CIP). Procedimientos para pruebas de evaluación estándar de clones avanzados de papa. Perú: CIP, 2009.

EMPRESA BRASILEIRA DE PESQUISA AGROPECUÁRIA (Embrapa). Sistema de produção da batata. 2. ed. Brasília, DF: Embrapa, 2016.

ESTEFAN, G.; SOMMER, R.; RYAN, J. Methods of soil, plant, and water analysis: a manual for the west Asia and north Africa region. 3. ed. Beirut: Icarda, 2013.

FELTRAN, J. C.; LEMOS, L. B. Características agronômicas e distúrbios fisiológicos em cultivares de batata. Cientifica, v. 33, n. 1, p. 106-113, 2005.

FERNANDES, A. M.; SORATTO, R. P.; EVANGELISTA, R. M.; NARDIN, I. Qualidade físico-química e de fritura de tubérculos de cultivares de batata na safra de inverno. Horticultura Brasileira, v. 28, n. 3, p. 299-304, 2010 a.

FERNANDES, A. M.; SORATTO, R. P.; SILVA, B. L. Extração e exportação de nutrientes em cultivares de batata: I. Macronutrientes. Revista Brasileira de Ciência do Solo, v. 35, n. 6, p. 2039-2056, 2011.

FERNANDES, A. M.; SORATTO, R. P.; SILVA, B. L.; SOUZA-SCHLICK, G. D. Crescimento, acúmulo e distribuição de matéria seca em cultivares de batata na safra de inverno. Pesquisa Agropecuária Brasileira, v. 45, n. 8, p. $826-835,2010$ b.

FITZPATRICK, T. J.; PORTER, W. L.; HOUGHLAND, G. V. C. Continued studies of the relationship of specific gravity to total solids of potatoes. American Potato Journal, v. 46, n. 4, p. 120-127, 1969.
KUMAR, D.; EZEKIEL, R.; SINGH, B.; AHMED, I. Conversion table for specific gravity, dry matter and starch content from under water weight of potatoes grown in north-Indian plains. Potato Journal, v. 32, n. 1-2, p. 79$84,2005$.

MELITO, S.; GARRAMONE, R.; VILLANO, C.; CARPUTO, D. Chipping ability, specific gravity and resistance to Pectobacterium carotovorum in advanced potato selections. New Zealand Journal of Crop and Horticultural Science, v. 45, n. 2, p. 81-90, 2017.

PEIXOTO, C. P.; CRUZ, T. V.; PEIXOTO, M. F. S. P. Análise quantitativa do crescimento de plantas: conceitos e prática. Enciclopédia Biosfera, v. 7, n. 13, p. 51-76, 2011.

PEREIRA, A. S.; NAZARENO, N. R. X.; SILVA, G. O.; BERTONCINI, O.; CASTRO, C. M.; HIRANO, E.; BORTOLETTO, A. C.; TREPTOW, R. O.; DUTRA, L. F.; LIMA, M. F.; GOMES, C. B.; KROLOW, A. C. R.; MEDEIROS, C. A. B.; CASTRO, L. A. S.; SUINAGA, F. A.; LOPES, C. A.; MELO, P. E. BRSIPR Bel: cultivar de batata para chips com tubérculos de boa aparência. Horticultura Brasileira, v. 33, n. 1, p. 135-139, 2015.

PEREIRA, A. S.; SIlVA, G. O.; CASTRO, C. M.; CARVALHO, A. D. F.; AZEVEDO, F. Q.; HIRANO, H.; BRITTO, G. G.; BORTOLETTO, A.; REISSER JUNIOR, C.; RAGASSI, C. F.; LOPES, C. A.; DUTRA, L. F.; CORADIN, J. H.; PINHEIRO, N. L.; GOMES, C. B.; PINHEIRO, J. B.; LOURENÇO JUNIOR, V.; LIMA, M. F.; MALDONADE, I. R.; EMYGDIO, B. M.; JORGE, R. O.; MELO, P. E. 'BRS F183' (Potira), uma nova cultivar de batata para processamento e mercado fresco. Batata Show, v. 20, n. 57, p. 16-17, 2020.

PINTO, C.; TEIXEIRA, A.; NEDER, D. Potencial de clones elite de batata como novas cultivares para Minas Gerais. Horticultura Brasileira, v. 28, n. 4, p. 399-405, 2010 .

POHL, S.; LOPES, N. F.; JACIRA, E.; BRAGA, B.; PEREIRA, C.; SÉRGIO, F. Características de crescimento de plantas de batata, cv. Baronesa, e seu genótipo transformado geneticamente para resistência ao PVY. Revista Ceres, v. 56, n. 6, p. 736-743, 2009.

SANTOS, H. G. dos; JACOMINE, P. K. T.; ANJOS, L. H. C. dos; OLIVEIRA, V. A.; LUMBRERAS, J. F.; COELHO, M. R.; ALMEIDA, J. A.; ARAUJO FILHO, J. C.; OLIVEIRA, J. B.; CUNHA, T. J. F. Brazilian soil classification system. 5. ed. Brasília, DF: Embrapa Solos, 2018.

SILVA, G. O.; PEREIRA, A. S.; AZEVEDO, F. Q.; CARVALHO, A. D. F.; PINHEIRO, J. B. Selection of potato clones for tuber yield, vine maturity, and frying quality. Horticultura Brasileira, v. 36, n. 2, p. 276-281, 2018 . 
SILVA, G. O.; PEREIRA, A. S.; BAIL, F. E.; PONIJALEKI, R.; CARVALHO, A. D. F. Resposta de cultivares de batata a níveis crescentes de NPK. Revista Ceres, v. 64, n. 5, p. 492-499, 2017.

SILVA, T. A.; PEREIRA, A. S. Melhoramento genético de batata para processamento na forma de palitos pré-fritos. Batata Show, v. 19, n. 55, p. 36-39, 2019.
TEIXEIRA, A. L.; SILVA, C. A.; PEIXOTO, L. S.; LEPRE, A. L. Eficiência na emergência e produtividade dos diferentes tipos de batata-semente. Scientia Agraria, v. 11, n. 3, p. 215-220, 2010.

UNITED STATES DEPARTMENT OF AGRICULTURE (USDA). Soil taxonomy: a basic system of soil classification for making and interpreting soil surveys. 2. ed. Washington, DC: USDA; 1999. 